\title{
Methane Production Potential of Food Waste and Food Waste Mixture with Swine Manure in Anaerobic Digestion
}

\author{
Mohammad Nazrul Islam, Keum Joo Park ${ }^{2 *}$, Hyung Sun Yoon ${ }^{3}$ \\ ${ }^{1}$ Department of Environmental Engineering, College of Engineering, Chonnam National University, Gwangju, Korea, \\ ${ }^{2}$ Department of Industrial Machinery Engineering, College of Life Science \& Natural Resources, Sunchon National \\ University, Suncheon, Korea, ${ }^{3}$ Korea Industrial Complex Corp. Jeonnam EIP Development Division, Yeosu, Korea
}

Received: April 23 ${ }^{\text {th }}, 2012$; Revised: April 25 ${ }^{\text {th }}, 2012$; Accepted: April 27 ${ }^{\text {th }}, 2012$

\section{Abstract}

Purpose: Methane production potential in aerobic digestion was assessed according to feed to inoculum (F/I) ratio for food waste only, and mixing ratio of two materials for food waste and swine manure to give a basic data for the design of anaerobic digestion system. Methods: Anaerbic digestion test was performed using a lab scale batch reactor at $35^{\circ} \mathrm{C}$ for six different feed to inoculum (F/I) ratios $(0.50,0.72,1.14,1.50,2.14$ and 3.41), three food waste to swine manure ratios (100:0, 60:40 and 40:60) with two different loading concentrations (10g VS/L and 30g VS/L). Results: For food waste only, the highest biogas yield of $1008 \mathrm{~mL} / \mathrm{gVS}$ was obtained at $0.50 \mathrm{of}$ F/I. For the co-digestion of food waste and swine manure mixture, the highest biogas yield of $1148 \mathrm{~mL} / \mathrm{gVS}$ was obtained at a mixing ratio of 40:60 with loading concentration of $10 \mathrm{~g}$ VS/L. Conclusions: F/I ratio for the food waste only, mixing ratio of food waste and swine manure, and co-substrate loading rate affected the biogas production rate. For the low loading rate, there was not so much difference according to the mixing ratio of food waste and swine manure, but for the high loading rate higher biogas yield was acquired for the co-digestion of food waste and swine manure than for the food waste alone (mixing ratio, 100:0).

Keywords: Food waste, Swine manure, Anaerobic digestion, Biogas yield, Codigestion, Feed to inoculum (F/I) ratio

\section{Introduction}

Incineration of Korean food waste is not a desirable method for disposing waste due to the high moisture contents and low heating value of food waste. Consequently, mesophilic anaerobic digestion has been one of the most widely used methods for food waste disposal. Co-digestion has been regarded as another way to improve the production of methane gas (Kim et al., 2010). It offers several advantages including dilution of toxic compounds, improved balance of nutrients and better biogas yield (Sosnowski et al., 2003). Manure has been used as a co-substrate for anaerobic digestion of food waste. The major advantage of using manures as a co-

\footnotetext{
*Comesponding author: Keum Joo Park

Tel: +82-61-750-3267; Fax: +82-61-750-3260

E-mail: pkj@sunchon.ac.kr
}

substrate is that it helps to overcome $\mathrm{pH}$ issues caused by the volatile fatty acids (VFA) produced from the digestion of food waste (Banks et al., 1998; Kafle et al., 2012). Anaerobic digestion is a biological approach for the treatment of organic waste and the production of biogas, which can be used as a fuel for heating or generating electricity (Zhang et al., 2010). When burned, a cubic foot $\left(0.028 \mathrm{~m}^{3}\right)$ of biogas yields about $10 \mathrm{Btu}(2.52 \mathrm{Kcal})$ of heat energy per percentage of methane composition (USDE, 2010). For example, biogas composed of $60 \%$ methane yields $600 \mathrm{Btu} / \mathrm{ft}^{3}\left(5400 \mathrm{kcal} / \mathrm{m}^{3}\right)$. In Korea, the amount of food waste generated each day reached 14,452 tons in 2007 (KME, 2008). In addition, the number of swine farms has rapidly grown in Korea due to increasing demand for meat. Swine manure (SM) production is about 150,000 tons/day and approximately $5.7 \%$ of the produced swine manure is disposed of by ocean dumping 
(Shin et al., 2008). In addition, it is major source of odor production, vermin attraction, toxic gas emission and ground water contamination. Due to the recent ban on direct disposal of food waste and swine manure into a landfill sites and seawater, waste reduction and recycling has been an issue in Korea. This research was carried out to characterize food waste and swine manure and assess their potential use as a feed stock in a mesophilic anaerobic digester.

\section{Materials and Methods}

\section{Feedstock and inoculum}

Food waste (FW) and swine manure (SM) samples were collected from the cafeteria and swine farm of Sunchon National University, respectively. The samples were transported immediately to the farm power laboratory at SCNU and stored in a refrigerator at approximately $4^{\circ} \mathrm{C}$. The food waste consisted of rice, fish, pork, banana skin, cabbage soup, vegetables and paste. The characteristics of the food waste, swine manure and inoculum are shown in Table 1.
Food waste was crusted using an electric crusher (M-DA 338, Daeseong, Korea) within 2 minutes and the swine manure was sieved (Sieve No. 20, Aperture: $850 \mathrm{~m}$ ) in order to remove large particles prior to feeding. Inoculum was collected from an anaerobic digester in a local swine manure treating plant.

\section{Batch digester and experimental procedure}

A triangle glass flask of $200 \mathrm{~mL}$ was used to carry out the anaerobic digestion tests. The working volume of the digester was $120 \mathrm{~mL}$. The batch tests were conducted using food waste only and mixtures of food waste and swine manure as the substrate for anaerobic digestion. In the food waste test (R1-R6), the inoculum was supplied at different feed to inoculum (F/I) ratios. In experiments that examined the mixture of food waste and swine manure (R7-R12), each digester contained the same amount of inoculum $(20 \mathrm{~mL})$. The $\mathrm{F} / \mathrm{I}$ ratio of the reactor was expressed as the amount of feedstock (food waste) VS per amount of inoculum VS (Liu et al., 2009). The experimental design is shown in Table 2. At mesophilic temperature, food waste was digested at six F/I ratios: $0.50,0.72,1.14,1.50,2.14$ and 3.41. Food waste and

Table 1. Basic characteristics of feed materials (average value)

\begin{tabular}{|c|c|c|c|}
\hline Parameters & Food waste & Swine manure & Inoculum \\
\hline tCOD (g/L) & 371.29 & 23.55 & 49.50 \\
\hline sCOD (g/L) & 90.54 & 9.80 & 15.60 \\
\hline $\mathrm{NH}_{3}-\mathrm{N}(\mathrm{g} / \mathrm{L})$ & 2.07 & 0.03 & 12.63 \\
\hline VFA $\left(\mathrm{CH}_{3} \mathrm{COOH}\right)(\mathrm{g} / \mathrm{L})$ & 25.42 & 17.70 & 2.40 \\
\hline Alkalinity $\left(\mathrm{CaCO}_{3}\right)(\mathrm{g} / \mathrm{L})$ & 41.70 & 26.40 & 15.90 \\
\hline TS (\%) & 17.94 & 1.32 & 45.32 \\
\hline VS (\%) & 13.41 & 0.53 & 7.94 \\
\hline $\mathrm{MC}(\%)$ & 82.06 & 98.68 & 54.68 \\
\hline
\end{tabular}

Remark: Analysis was repeated with duplicate samples.

Table 2. Experimental design and biogas production performance

\begin{tabular}{|c|c|c|c|c|c|c|c|}
\hline Reactor & $\begin{array}{l}\text { Initial loading } \\
\quad(\mathrm{g} \mathrm{VS} / \mathrm{L})\end{array}$ & $\mathrm{F} / \mathrm{l}$ ratio & $\begin{array}{c}\text { Biogas yield } \\
\text { (mL/gVS) }\end{array}$ & Reactor & $\begin{array}{l}\text { Initial loading } \\
\quad(\mathrm{g} \mathrm{VS/L)}\end{array}$ & $\begin{array}{l}\text { Ratio of FW to } \\
\text { SM (\% volume } \\
\text { basis) }\end{array}$ & $\begin{array}{c}\text { Biogas yield } \\
\text { (mL/gVS) }\end{array}$ \\
\hline R1 & 10 & 0.50 & 1008 & $\mathrm{R} 7$ & 10 & $100: 0$ & 925 \\
\hline $\mathrm{R} 2$ & 10 & 0.72 & 952 & $\mathrm{R} 8$ & 10 & $60: 40$ & 1113 \\
\hline R3 & 10 & 1.14 & 720 & $\mathrm{R} 9$ & 10 & $40: 60$ & 1148 \\
\hline R4 & 30 & 1.50 & 127 & R10 & 30 & 100:0 & 110 \\
\hline R5 & 30 & 2.14 & 111 & R11 & 30 & $60: 40$ & 814 \\
\hline $\mathrm{R} 6$ & 30 & 3.41 & 151 & $\mathrm{R} 12$ & 30 & $40: 60$ & 586 \\
\hline
\end{tabular}


mixtures of food waste and swine manure (100:0, 60:40, 40:60, \% volume basis) were digested at two initial volatile solids (VS) loading concentrations: 10 and $30 \mathrm{~g}$ VS/L.

After adding the required amount of substrates, the digester was purged with nitrogen gas for $2 \mathrm{~min}$ to assure an anaerobic condition before it was tightly closed with a rubber stopper. The reactors were kept on a laboratory shaking incubator (VS-8480SF, Vision Scientific Co. Ltd, Korea) at a temperature of $35^{\circ} \mathrm{C}$, which was within the optimal temperature for the mesophilic bacteria (Henstra et al., 2007). Continuous and homogeneous mixing was achieved using an automatic stirring laboratory shaker at $120 \mathrm{rpm}$. Each batch digester was connected to the needle blocked by a rubber stopper to stop the leakage of gas and liquid as shown in Figure 1. The produced biogas forced to move the piston of medical syringe through the needle by the pressure difference when opening the gate valve.

\section{Biogas measurement and analytical methods}

Biogas was removed from the digester by pressing the needle into the rubber stopper. After connecting the needle, biogas produced inside the digester was moved into the syringe by expanding the volume (piston moves). The volume of the produced biogas was recorded by reading the scale on the syringe twice a day. Analysis of food waste and swine manure samples was conducted before digestion and after 30 days of digestion. Total chemical oxygen demand (tCOD), total solids (TS) and VS of the mixed samples were determined according to standard methods (APHA, 2005). Soluble COD (sCOD), VFA (as $\mathrm{CH}_{3} \mathrm{COOH}$ ) and $\mathrm{NH}_{3}-\mathrm{N}$ were analyzed after centrifugation at $4000 \mathrm{rpm}$ for 10 minutes. Alkalinity (as $\mathrm{CaCO}_{3}$ ) was determined by the close reflux, titrimetric
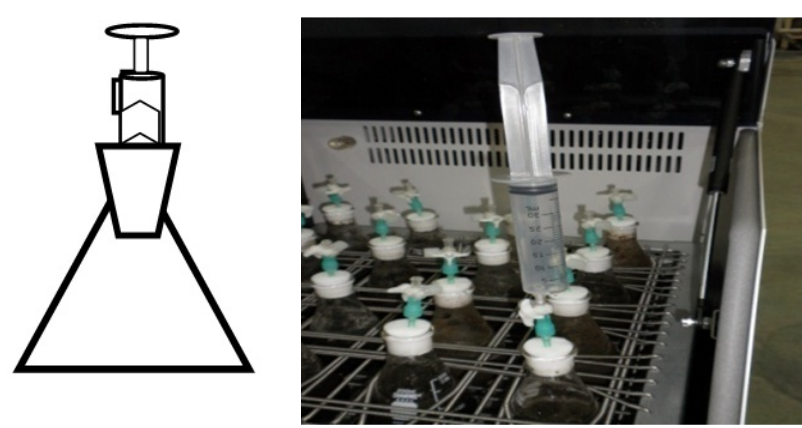

Figure 1. Schematic diagram and picture of the laboratory experimental batch test. method according to standard methods (APHA, 2005). The $\mathrm{pH}$ value was measured using a $\mathrm{pH}$ meter (EGA 133/BNC, Sechang Instruments, Korea).

\section{Results and Discussion}

The average daily biogas production and cumulative biogas production during the digestion of food waste at six different F/Is are shown in Figure 2. Daily biogas production ranged from $20 \mathrm{~mL} / \mathrm{gVS}$-day to $80 \mathrm{~mL} / \mathrm{gVS}$ day at low F/I ratios (F/I: 0.50, 0.72 and 1.14), whereas, biogas production gradually decreased at the higher F/Is. The peak value of daily biogas production rates was calculated to be $83 \mathrm{~mL} / \mathrm{g}$ VS-day after the $9^{\text {th }}$ day of digestion at a F/I ratio of 0.5 .

The accumulated biogas yields were measured to be $1008,952,720,127,111$, and $151 \mathrm{~mL} / \mathrm{g} \mathrm{VS}$ at F/I ratios of $0.50,0.72,1.14,1.50,2.14$, and 3.41 , respectively, indicating that the yields decreased with an increase in $\mathrm{F} / \mathrm{I}$ ratio. The highest biogas yield obtained was $1008 \mathrm{~mL} / \mathrm{g}$ $\mathrm{VS}$ at a F/I ratio of 0.50 . A fairly similar biogas yield (952 $\mathrm{mL} / \mathrm{g}$ VS) was obtained at a F/I ratio of 0.72 . At higher F/I ratios (1.50, 2.14 and 3.41), a total biogas yield of about $90 \%$ was achieved during the first five days of digestion. These results indicate that the lower $\mathrm{F} / \mathrm{I}$ ratio $(0.50,0.72$ and 1.14) is desirable for effective digestion of food
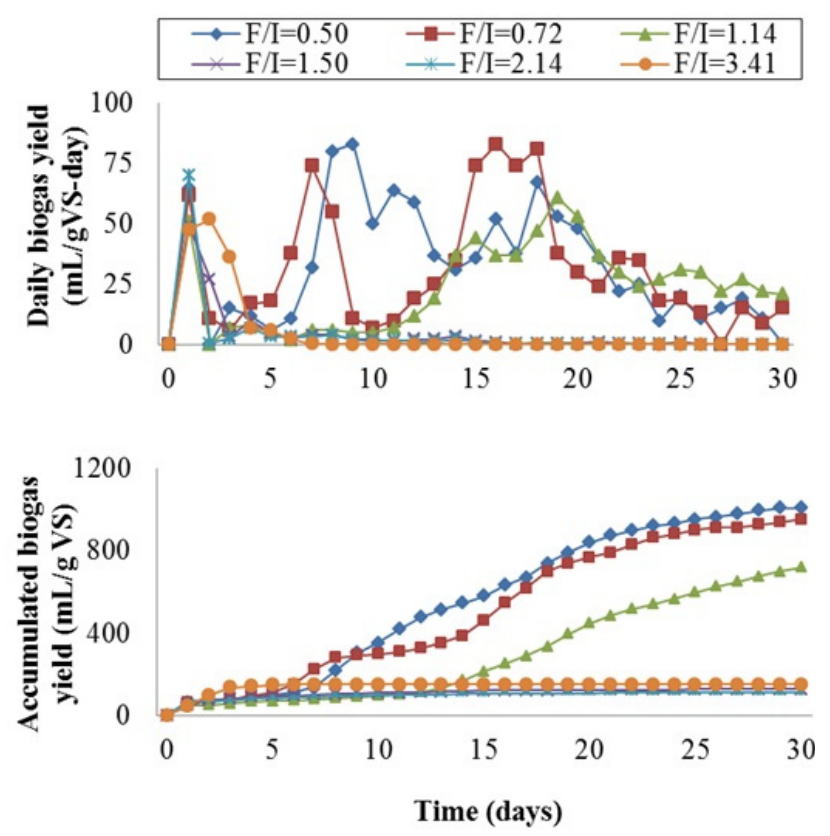

Figure 2. Daily and accumulated biogas yield from mesophilic anaerobic digestion of food waste at six different F/ls. 
waste.

The accumulated biogas yield were measured to be 925, 1113.5 , and $1148.5 \mathrm{~mL} / \mathrm{g}$ VS when the organic load concentration was $10 \mathrm{~g} \mathrm{VS} / \mathrm{L}$ at mixing ratios of 100:0, 60:40 and 40:60 (FW: SM), respectively (Figure 3). At a organic loading concentration of $30 \mathrm{~g} \mathrm{VS} / \mathrm{L}$, the biogas yield was 110,814 , and $584.6 \mathrm{~mL} / \mathrm{g}$ VS at mixing ratios of 100:0, 60:40 and 40:60, respectively, after 30 days of digestion (Figure 4 and Table 2). The highest biogas yield
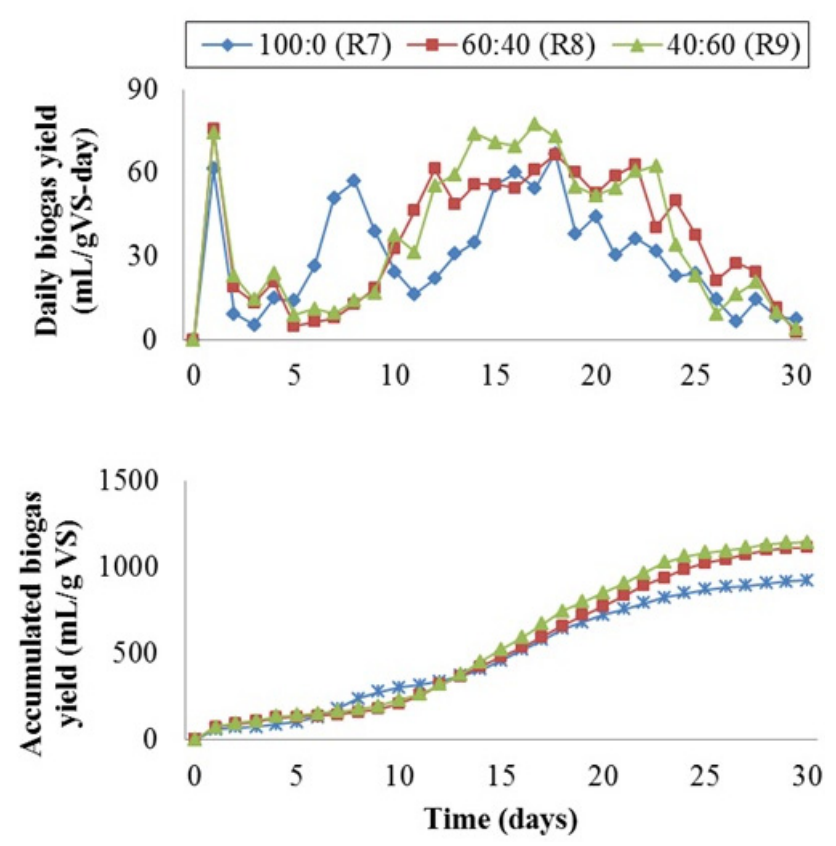

Figure 3. Daily and accumulated biogas yield from mesophilic anaerobic digestion of food waste at three different mixing ratios for initial organic loading of $10 \mathrm{~g} \mathrm{VS} / \mathrm{L}$. obtained was $1148.5 \mathrm{~mL} / \mathrm{g}$ VS at a mixing ratio of 40:60 and organic load concentration of $10 \mathrm{~g} \mathrm{VS} / \mathrm{L}$.

These results demonstrate that biogas yields after 30 days of digestion of food waste are influenced by the mixing ratio of food waste and swine manutre and the F/I ratio. In this study, a higher biogas yield was achieved (1008 mL/g VS) at a lower F/I of 0.5 and lower biogas yields were observed at higher F/I ratios. This inverse relation might be due to the low methanogenic activity
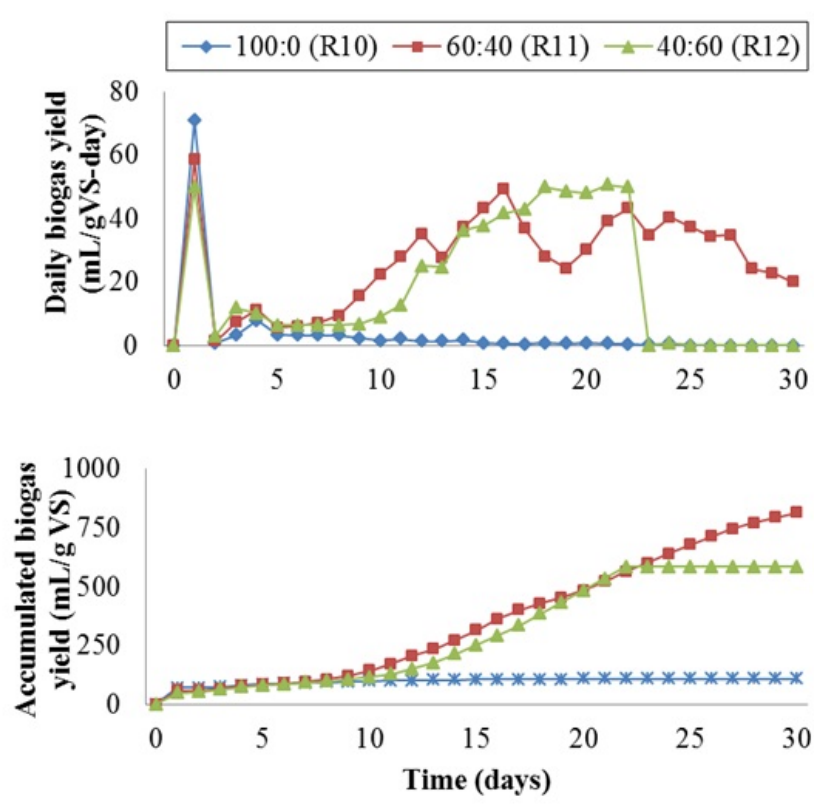

Figure 4. Daily and accumulated biogas yield from mesophilic anaerobic digestion of food waste at three different mixing ratios for initial organic loading of $30 \mathrm{~g} \mathrm{VS} / \mathrm{L}$.

Table 3. Characteristics of digested waste (after 30 days of digestion)

\begin{tabular}{|c|c|c|c|c|c|c|}
\hline Reactor & $\mathrm{pH}$ & $\begin{array}{c}\text { Alkalinity (as } \mathrm{CaCO}_{3} \text { ) } \\
\mathrm{mg} / \mathrm{L}\end{array}$ & $\begin{array}{l}\mathrm{NH}_{3}-\mathrm{N} \\
\mathrm{mg} / \mathrm{L}\end{array}$ & $\begin{array}{l}\mathrm{sCOD} \\
\mathrm{mg} / \mathrm{L}\end{array}$ & $\begin{array}{c}\left.\text { VFA (as } \mathrm{CH}_{3} \mathrm{COOH}\right) \\
\mathrm{mg} / \mathrm{L}\end{array}$ & VFAValkalinity ratio \\
\hline $\mathrm{R} 1$ & 7.90 & 12000 & 1640 & 3070 & 850 & 0.11 \\
\hline $\mathrm{R} 2$ & 7.87 & 7900 & 1690 & 3520 & 1300 & 0.11 \\
\hline R3 & 7.74 & 8500 & 695 & 2190 & 6450 & 0.82 \\
\hline $\mathrm{R} 4$ & 6.45 & 9900 & 1680 & 20430 & 8500 & 1.00 \\
\hline R5 & 6.80 & 6900 & 1900 & 20410 & 8300 & 0.84 \\
\hline R6 & 5.57 & 6900 & 885 & 20210 & 9250 & 1.34 \\
\hline $\mathrm{R} 7$ & 7.90 & 12000 & 690 & 3520 & 1300 & 0.11 \\
\hline R8 & 8.09 & 11900 & 1335 & 6000 & 1300 & 0.11 \\
\hline R9 & 7.15 & 14100 & 1785 & 7080 & 1150 & 0.08 \\
\hline R10 & 6.80 & 9900 & 900 & 20410 & 6800 & 0.69 \\
\hline $\mathrm{R} 11$ & 7.09 & 15100 & 2310 & 8750 & 1100 & 0.07 \\
\hline $\mathrm{R} 12$ & 7.86 & 12300 & 2705 & 20350 & 2000 & 0.16 \\
\hline
\end{tabular}


and/or number of methogens in the digesters, which produce excess VFA during the acidogenic step. High concentrations of VFA could inhibit methanogenesis (Liu et al., 2009).

Generally, FW is thought of as being highly degradable, but a adequately high alkalinity is required for sucessful digestion. Callaghan et al. (2002) reported that, for balanced digestion of FW alone or with co-substrates, the alkalinity should not be less than $1500 \mathrm{mg} / \mathrm{L}$. The toxic and inhibitory inorganic compounds of $\mathrm{NH}_{3}-\mathrm{N}$ can be problematic to the anaerobic process should be and should be within the range of 50-500 mg/L for normal digestion (Tchobanoglous et al., 2003). Throughout this study using food waste, the alkalinity was always greater than $5000 \mathrm{mg} / \mathrm{L}$.

The stability of the digestion system depends on a number of factors, such as $\mathrm{pH}, \mathrm{VFA}, \mathrm{NH}_{3}-\mathrm{N}$ and alkalinity, etc. The result of alkalinity, $\mathrm{NH}_{3}-\mathrm{N}, \mathrm{sCOD}, \mathrm{VFA}$, and VFA:alkalinity ratio of each reactor are presented in Table 3. One of the most important criteria to digester stability is the VFA:alkalinity ratio. Callaghan et al. (2002) reported that the VFA:alkalinity ratio should be less than 0.7 .

As shown in Table 2, some of reactor's (R4, R5, R6, R10) biogas yields were very low, which may have been due to digester instability because of the high VFA concentrations and VFA:alkalinity ratios (Table 3).

\section{Conclusions}

The effects of different substrate loading rates, feed to inoculum (F/I) ratios and mixing ratios of food waste and swine manure on biogas yield from food waste and their mixture were studied using batch anaerobic digester under mesophilic conditions. In the food waste test (based on different $\mathrm{F} / \mathrm{Is}$ ), higher biogas yields were obtained at comparatively lower $\mathrm{F} / \mathrm{I}$ ratios for the six different $\mathrm{F} / \mathrm{Is}$. The highest biogas yield obtained was $1008 \mathrm{~mL} / \mathrm{g}$ VS at a $\mathrm{F} / \mathrm{I}$ ratio of 0.50 as shown in Table 2 and Figure 2. In the food waste and swine manure test (based on mixing ratio), the highest biogas yield obtained was $1148.5 \mathrm{~mL} / \mathrm{g}$ VS at a mixing ratio of 40:60 (FW: SM) and organic loading concentration of $10 \mathrm{~g}$ VS/L as shown Table 2 and Figures 3 and 4 . Results from this study suggest that food waste and swine manure are potential substrates for anaerobic digestion for the production of biogas. As a result, anaerobic co-digestion of food waste and swine manure was more effective in terms of biogas production than single digestion of food waste. The data obtained in this study could be used as a basis for designing large scale anaerobic digesters for the treatment of food waste and mixtures of food waste and swine manure.

\section{Conflict of Interest}

No potential conflict of interest relevant to this article was reported.

\section{Acknowledgement}

This research was supported by the program for the construction of Eco Industrial Park (EIP) which was conducted by the Korea Industrial Complex Corporation (KICOX) and the Ministry of Knowledge Economy (MKE).

\section{References}

Banks, C. J. and P. N. Humphreys. 1998. The anaerobic treatment of a lingo-cellulosic substrates offering natural $\mathrm{pH}$ buffering capacity. Water Science and Technology 38(4-5):29-35.

Callaghan, F. J., D. A. J. Wase, K. Thayanithy and C. F. Forster. 2002. Continuous co-digestion of cattle slurry with fruit and vegetable wastes and chicken manure. Biomass Bioenergy 27(1):7177.

Kafle, G. K., S. H. Kim and B. S. Shin. 2012. Anaerobic digestion treatment for the mixture of Chinese cabbage waste juice and swine manure. Journal of Biosystems Engineering 37(1):58-64.

Kim, S. H and G. K. Kafle. 2010. Effective treatment of swine manure with Chinese cabbage silage through two serial anaerobic digestion. Journal of Biosystems Engineering 35(1): 53-62.

Henstra, A. M., J. Sipma, A. Rinzema and A. J. M. Stams. 2007. Microbiology of synthesis gas fermentation for biofuel production. Current option in Biotechnology 18:200-206.

KME. 2008. Statistics of current status of waste disposal. Korea Ministry of Environment. Available at: http:// eng.me.go.kr. Accessed 15 December 2010. 
Liu, G., R. Zhang, M. H. El-Mashad and R. Dong. 2009. Effect of feed to inoculums ratios on biogas yields of food and green wastes. Bioresource Technology 100:5103 $-5108$.

Sosnowwski, P., A. Wieczorek and S. Ledakowicz. 2003. Anaerobic co-digestion of sewage sludge and organic fraction of municipal solid wastes. Advances in Environmental Research 7(3):609-616.

Shin, J. D., S. S. Han, K. C. Eom, S. Sung, S. W. Park and H. Kim. 2008. Predicting methane production potential of anaerobic co-digestion of swine manure and food waste. Environmental Engineering Research 13(2):
93-97.

Tchobanoglous, G., F. L. Burton and H. D. Stensel. 2003. Wastewater Engineering: Treatment and Reuse. Metcalf \& Eddy, Inc., McGraw-Hill, Boston.

USDE. 2010. United State Department of Energy. Available at: http://www. energysavers.gov/your_workplace/ farms_ranches/index.cfm/mytopic $=30003$. Accessed 20 March 2011

Zhang, R. and H. M. El-Mashad. 2010. Biogas production from co-digestion of dairy manure and food waste. Bioresource Technology 101:4021-4028. 